\title{
The Influence of Educational Attainment on Teenage Pregnancy in Low-Income Countries: A Systematic Literature Review
}

\author{
Rebekah Mohr \\ Stephen F. Austin State University \\ Jose Carbajal \\ Stephen F. Austin State University \\ Bonita B. Sharma \\ The University of Texas at San Antonio
}

\begin{abstract}
The purpose of this study is to review the association between education and teenage pregnancy in low- and lower-middle-income countries. Teenage pregnancy deters women from achieving educational goals and from maximizing their human capital. This study was conducted using the Preferred Reporting Items for Systematic Reviews and Meta-Analyses statement. Nine out of 4,980 articles scanned met the inclusion criteria for analysis, from 2008 to 2018 . The results show reaching higher levels of education deters from teenage pregnancy in low- and lower-middle-income countries. Therefore, social work policies and programs should target access to education and school retention as a deterrence to teenage pregnancy.
\end{abstract}

Keywords: education, teenage pregnancy, low-income countries, adolescent pregnancy, developing countries

\section{Introduction}

One of the Grand Challenges for Social Work is to ensure healthy development for all youth (Uehara et al., 2015). Raising healthy adolescents can promote positive development cycle intergenerationally. More schooling or higher level of educational attainment is a protective factor against teenage pregnancy (Gupta \& Mahy, 2003; Sahoo, 2011). Additionally, promoting global education and awareness of global social issues, such as addressing teenage pregnancy through improving educational attainment, is important for social workers and practitioners.

Teenage pregnancy is a global youth development issue. According to the World Health Organization (WHO; 2018), an average of 16 million girls between 15 and 19 years old give birth every year, and low- and lower-middle-income countries ${ }^{1}$ are at higher risk for teenage pregnancy (Santelli, Song,

1 According to the World Bank Data Team (2019), based on their Atlas method of calculation in U.S. dollars, as of July 2018, low-income countries have $\$ 995$ in Gross National Income per capita. These countries are Afghanistan, Albania, Algeria, American Samoa, Belarus, Belize, Benin, Bosnia and Herzegovina, Burkina Faso, Burundi, Central African Republic, Chad, Comoros, Congo Democratic Republic, Eritrea, Ethiopia, The Gambia, Guinea, GuineaBissau, Haiti, Liberia, Madagascar, Malawi, Mali, Mozambique, Nepal, Niger, Rwanda, 
Garbers, Sharma, \& Viner, 2017; see Footnote 1 for which countries are considered low- and lowermiddle income countries, as this article focuses on both categories). Teenage pregnancy has been identified as one of the major contributors toward maternal and child morbidity and mortality rates (Jonas, Crutzen, van den Borne, Sewpaul, \& Reddy, 2016). Chances of stillbirths, newborn deaths, and low birth weight for infants born of adolescent mothers increase significantly compared to those born to mothers aged 20-29 (WHO, 2014). Additionally, teenage pregnancy reduces many life opportunities for young girls, such as education, employment, and better income. Teenagers who become pregnant are more likely to discontinue school or at least not reach the same educational levels as their peers who do not become pregnant (Azevedo et al., 2012; Ferre, Gerstenblüth, Rossi, \& Triunfo, 2013). Teenage mothers who drop out of school and do not pursue higher education limit their opportunities (Mesa \& Torres, 2016). Furthermore, children of teenage mothers are more likely to grow up and repeat parents' teenage reproductive behaviors (Azevedo et al., 2012). Therefore, the teenage pregnancy cycle continues to the next generation, making positive youth development a challenge.

Thus, teenage pregnancy has become a global issue in low- and lower-middle-income countries. Cultural norms and policies, which force children into motherhood have influenced teen pregnancy (Odimegwu \& Mkwananzi, 2016). According to the United Nations Population Fund (2013), 4 million Indian girls aged 15-19 give birth annually, accounting for $16 \%$ of all births in India alone. In Latin America, Nicaragua has the highest rates of teenage pregnancy in the region. The challenge of teenage pregnancy among low- and lower-middle-income countries continues to rise, as poor education and poverty contribute to higher rates of teenage pregnancy (Azevedo et al., 2012; Handa et al., 2009; Decat et al., 2015).

Poverty, such as in low- and lower-middle income-countries, is a grave issue and it plays a significant cyclical and compounding role in the level of education and rate of teenage pregnancy (Ferre et al., 2013). According to the World Bank (2019), the majority of the global poor are poorly educated rural youth, under the age of 18, who lack opportunities and depend on agricultural labor. Poverty limits freedom, opportunities, and resources and creates conditions for powerlessness, exclusion and vulnerabilities. Such vulnerabilities can create increased conditions for lack of education and teenage pregnancy. For example, poverty can drive adolescents to commit to early marriage and drop out from school. Adolescents with no formal education, a lower level of education, or who are not enrolled in school are more likely to become pregnant (Gomes, Speizer, Gomes, Oliveira, \& Moura, 2008; Omar et al., 2010). Additionally, many girls drop out from school when they feel marriage and pregnancy is a better option to their socioeconomic conditions, and in turn contribute to teenage pregnancy (World Bank, 2019).

Senegal, Sierra Leone, Somalia, South Sudan, Tanzania, Togo, Uganda, and Zimbabwe. Lower-middle-income countries have Gross National Income per capita from $\$ 996$ to $\$ 3,895$ as of July 2018. These countries are Angola, Bangladesh, Bhutan, Bolivia, Cabo Verde, Cambodia, Cameroon, Congo, Djibouti, Egypt, El Salvador, Georgia, Ghana, Honduras, India, Indonesia, Ivory Coast, Kenya, Kiribati, Kosovo, Kyrgyzstan, Laos, Lesotho, Mauritania, Micronesia, Moldova, Mongolia, Morocco, Myanmar, Nicaragua, Nigeria, Pakistan, Papua New Guinea, Philippines, Sao Tome and Principe, Solomon Islands, Sri Lanka, Sudan, Swaziland, Timor-Leste, Tunisia, Ukraine, Uzbekistan, Vanuatu, Vietnam, West Bank, Gaza, and Zambia. The selection inclusion criteria for our sample included countries from both the low- and lower-middle income categories. 
Lack of education contributes to teen pregnancy in low- and lower-middle-income countries (Decat et al., 2015; Handa et al., 2009). Education affects the life of individuals regardless of their social status and, those who live in low- and lower-middle-income countries receive a lower education than those in higher-income countries (Ferre et al., 2013). Michaelowa (2000) suggested a lack of basic education contributes to poverty because it reduces the chances of economic growth and quality of life, particularly for women. Therefore, teen pregnancy and lack of education is commonly associated with areas of poverty, making those countries which struggle with poverty more prone to experiencing higher rates of teenage pregnancy and lack of education among its young people (Bartlett et al., 2011; Decat et al., 2015).

The focus of this study is on conducting a systematic review on the influence educational attainment has on teenage pregnancy in low- and lower-middle-income countries. The association between lowand lower-middle-income countries and teen pregnancies highlights the high rate of teenage mothers in various parts of the world (Azevedo et al., 2012). Previous studies have focused on teenage pregnancy, education, and poverty. However, there has not been an effort to examine the relationship among these concepts. We examine empirical literature on teenage pregnancy and education in low- and lower-middle-income countries because teenagers are in greater danger of pregnancy complications, especially when there is limited access to resources (Azevedo et al., 2012; Samandari \& Speizer, 2010; WHO, 2014). The results from this study could aid social workers in designing effective programs and creating policies for teenage girls in low- and lower-middle-income countries, which might help them obtain better life opportunities.

Additionally, even though there is a general understanding between the relationship of education and teenage pregnancy risk, such generalizations seldom account for the threats to internal validity. Literature reviews, in general, suffer from selection bias. This study makes a unique contribution that addresses such issues with validity and reliability of research conducted on teenage pregnancy and education in the past by using preferred reporting items for systematic reviews and metaanalyses (PRISMA) and assessment of multiple systematic reviews (AMSTAR) guidelines, which provides a scientific approach toward assessing the level of bias in well-known and well-accepted findings in the field of social science.

\section{Method}

The design of this research study was a systematic literature review based on the PRISMA (Moher et al., 2015). The design of this research helped the researchers to synthesize any available data on the concepts of education and teenage pregnancy in low- and lower-middle-income countries. The research question guiding this study was this: How does educational attainment influence teenage pregnancy in low- and lower-middle-income countries?

\section{Literature Search and Retrieval Process}

We searched the following databases from January 2008 through July 2018: Academic Search Complete, CINAHL, Consumer Health Complete-EBSCOhost, Educational Administrative Abstracts, ERIC, Family Studies Abstract, Fuente Academia Premier, Google Scholar, MEDLINE, Professional Development Collection, PsycARTICLES, Psychology and Behavioral Sciences Collection, PsycINFO, Social Work Abstracts, and SocINDEX. The keywords entered for the eligibility criteria were teenage pregnancy, adolescent pregnancy, teen pregnancy, or youth pregnancy; education, school, or schooling; and low-income countries, developing countries, lower-middle-income countries, or third-world countries. The first author independently conducted the collection process, and the other two authors confirmed the data for inclusion. 


\section{Sampling}

The articles were assessed through PRISMA and AMSTAR (see Figure 1 and Table 1).

\section{Identification}

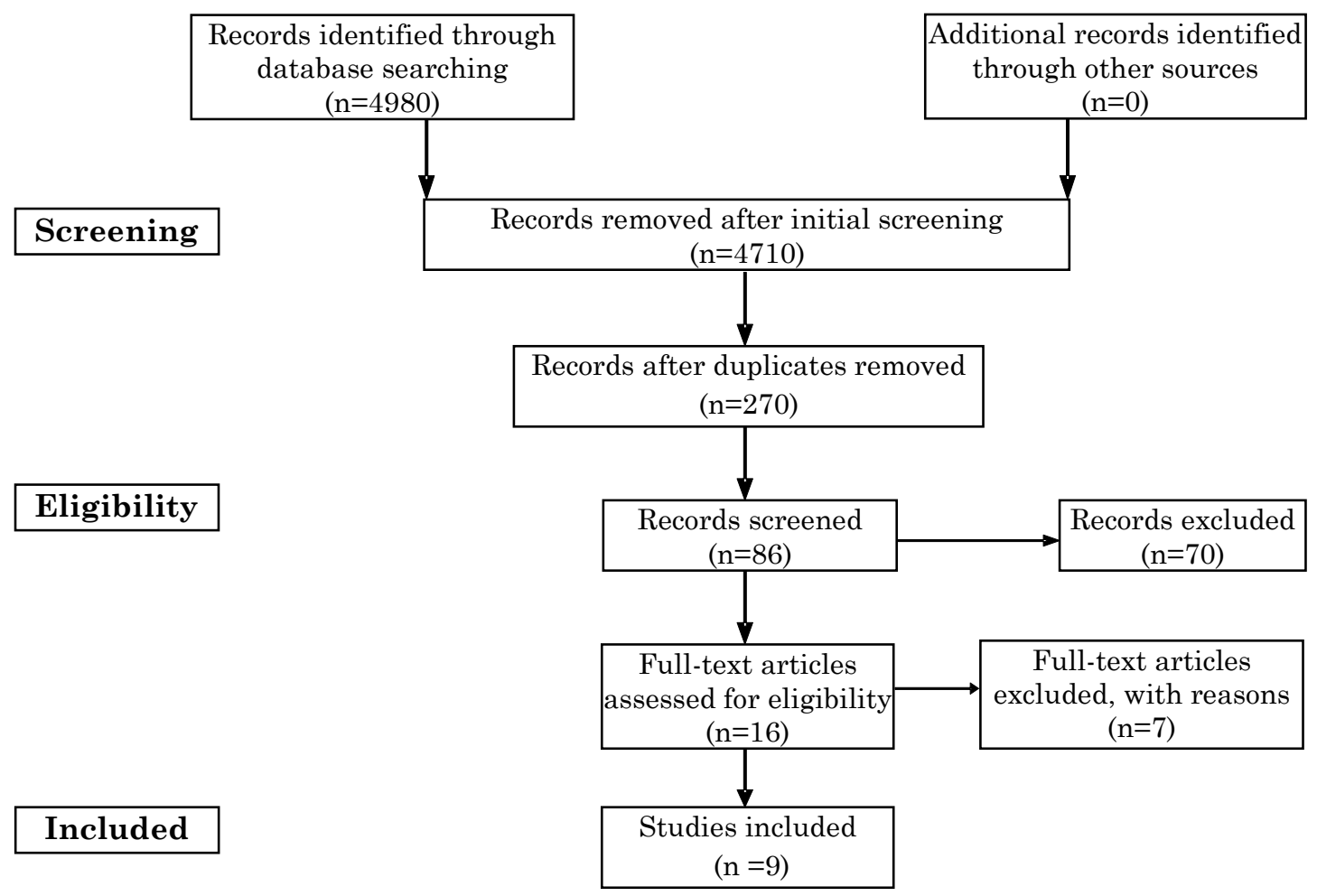

Figure 1. Selection of Studies 
Table 1. Characteristics of Included Studies

\begin{tabular}{|c|c|c|c|c|c|c|c|}
\hline & Review & AMSTAR & Study & & Research & & \\
\hline Study & by Type & Score & Design & Sample & Aim & Measure & Outcome \\
\hline $\begin{array}{l}\text { Acharya et } \\
\text { al. (2010) }\end{array}$ & $\begin{array}{l}\text { Systematic } \\
\text { review }\end{array}$ & 9.83 & $\begin{array}{c}\text { Systematic } \\
\text { review }\end{array}$ & $\begin{array}{l}\text { N=12; } \\
\text { Age }= \\
\text { adolescent } \\
\quad \text { (definition } \\
\text { not } \\
\text { provided) } \\
\text { Region = } \\
\text { South } \\
\text { Asian } \\
\text { Countries }\end{array}$ & $\begin{array}{l}\text { To identify } \\
\text { risk factors } \\
\text { associated } \\
\text { with } \\
\text { teenage } \\
\text { pregnancy }\end{array}$ & $\begin{array}{l}\text { Used National } \\
\text { Health Service } \\
\text { Centre for } \\
\text { Reviews and } \\
\text { Dissemination } \\
\text { guidelines }\end{array}$ & $\begin{array}{l}\text { Socioeconomic status, low educational } \\
\text { attainment, cultural and family } \\
\text { structure are risk factors for teenage } \\
\text { pregnancy }\end{array}$ \\
\hline $\begin{array}{l}\text { Aderibigbe } \\
\text { et al. } \\
\quad(2010)\end{array}$ & Quantitative & 2.26 & $\begin{array}{l}\text { Cross- } \\
\text { sectional } \\
\text { study }\end{array}$ & $\begin{array}{l}N=521 \\
\text { Age }=10-19 \\
\text { Region }= \\
\text { Ilorin, } \\
\quad \text { Nigeria }\end{array}$ & $\begin{array}{l}\text { To determine } \\
\text { the } \\
\text { outcomes of } \\
\text { teenage } \\
\text { pregnancy } \\
\text { in school }\end{array}$ & $\begin{array}{l}\text { Multistage } \\
\text { sampling } \\
\text { technique, and } \\
\text { structured } \\
\text { questionnaire }\end{array}$ & $\begin{array}{l}25.2 \% \text { Females were sexually active, of } \\
\text { which } 5.7 \% \text { were pregnant and } 66.7 \% \\
\text { had been pregnant at least once; all } \\
\text { the females who had been pregnant } \\
\text { had an abortion }\end{array}$ \\
\hline $\begin{array}{l}\text { Ayuba and } \\
\text { Gani } \\
(2012)\end{array}$ & Quantitative & 2.93 & $\begin{array}{l}\text { Retrospec- } \\
\text { tive cross- } \\
\text { section } \\
\text { over } 4 \\
\text { years }\end{array}$ & $\begin{array}{c}N=260(83 \\
\text { teenagers } \\
\text { and } 180 \\
\text { nonteen- } \\
\text { agers); Age } \\
=14-19 \\
\text { Region }= \\
\text { Niger Delta, } \\
\text { Nigeria }\end{array}$ & $\begin{array}{l}\text { To evaluate } \\
\text { risk factors } \\
\text { associated } \\
\text { with } \\
\text { teenage } \\
\text { pregnancy } \\
\text { and } \\
\text { determine } \\
\text { pregnancy } \\
\text { risk factors }\end{array}$ & $\begin{array}{l}\text { Hospital records, } \\
\text { used } \\
\text { systematic } \\
\text { random } \\
\text { sampling } \\
\text { technique }\end{array}$ & $\begin{array}{l}\text { Teenage pregnancy is more common } \\
\text { among girls with less education, who } \\
\text { are unemployed, who are unmarried, } \\
\text { and who do not have adequate } \\
\text { prenatal care, which led to poor } \\
\text { pregnancy outcome }\end{array}$ \\
\hline $\begin{array}{l}\text { Barmao- } \\
\text { Kiptanui } \\
\text { et al. } \\
\text { (2015) }\end{array}$ & $\begin{array}{l}\text { Quantitative } \\
\text { and } \\
\text { qualitative }\end{array}$ & 2.2 & $\begin{array}{l}\text { Semistruc- } \\
\text { tured } \\
\text { interviews } \\
\text { and survey }\end{array}$ & $\begin{array}{c}N=38(35 \\
\text { students } \\
\text { and } 3 \\
\text { teachers); } \\
\text { Age = } \\
\text { primarily } \\
13-14 \\
\text { years old; } \\
\text { Region = } \\
\text { Bungoma, } \\
\text { Kenya }\end{array}$ & $\begin{array}{l}\text { To investigate } \\
\text { the impact } \\
\text { of teenage } \\
\text { motherhood } \\
\text { on the } \\
\text { academic } \\
\text { performance }\end{array}$ & $\begin{array}{l}\text { Semistructured } \\
\text { interviews and } \\
\text { survey }\end{array}$ & $\begin{array}{l}\text { Education prepares girls for jobs, } \\
\text { livelihoods, and raises their self- } \\
\text { esteem, but teenage motherhood leads } \\
\text { to low educational attainment }\end{array}$ \\
\hline
\end{tabular}




\begin{tabular}{|c|c|c|c|c|c|c|c|}
\hline Study & $\begin{array}{l}\text { Review } \\
\text { by Type }\end{array}$ & $\begin{array}{c}\text { AMSTAR } \\
\text { Score }\end{array}$ & $\begin{array}{l}\text { Study } \\
\text { Design }\end{array}$ & Sample & $\begin{array}{c}\text { Research } \\
\text { Aim }\end{array}$ & Measure & Outcome \\
\hline $\begin{array}{l}\text { Beguy et } \\
\text { al. (2013) }\end{array}$ & Quantitative & 4.6 & $\begin{array}{l}\text { Retrospec- } \\
\text { tive cross- } \\
\text { sectional }\end{array}$ & $\begin{array}{l}N=897 \\
\text { Age }=15-19 \\
\text { Region }= \\
\text { Nairobi, } \\
\text { Kenya }\end{array}$ & $\begin{array}{l}\text { To investigate } \\
\text { patterns } \\
\text { and } \\
\text { determin- } \\
\text { ants of } \\
\text { entry into } \\
\text { motherhood }\end{array}$ & $\begin{array}{l}\text { Transition to } \\
\text { Adulthood } \\
\text { question- } \\
\text { naire }\end{array}$ & $\begin{array}{l}\text { Being married, out of school, and having } \\
\text { negative models in peer, in family, and at } \\
\text { school are associated with early } \\
\text { childbearing for females aged } 15-17 \text {; for } \\
\text { females aged } 18-19 \text {, school attendance } \\
\text { delays entry into motherhood }\end{array}$ \\
\hline $\begin{array}{l}\text { Exavery at } \\
\text { al. (2016) }\end{array}$ & Quantitative & 3.83 & $\begin{array}{l}\text { Retrospec- } \\
\text { tive cross- } \\
\text { sectional } \\
\text { over } 9 \\
\text { years }\end{array}$ & $\begin{array}{l}N=5,491 \\
\text { Age }=<18 \\
\text { Region }= \\
\quad \text { Rufiji, } \\
\text { Tanzania }\end{array}$ & $\begin{array}{l}\text { To examine } \\
\text { teenage } \\
\text { trends and } \\
\text { correlates of } \\
\text { childbearing }\end{array}$ & $\begin{array}{l}\text { Rufiji health } \\
\text { and } \\
\text { demogra- } \\
\text { phic } \\
\text { surveillance } \\
\text { system }\end{array}$ & $\begin{array}{l}44 \% \text { of First-time mothers are of childhood } \\
\text { age (<18 years); } 19 \% \text { never attended } \\
\text { school (education was the strongest } \\
\text { covariate predicting pregnancy); } 32 \% \\
\text { were married and } 53 \% \text { were single }\end{array}$ \\
\hline $\begin{array}{l}\text { Neal et al. } \\
\quad(2015)\end{array}$ & Quantitative & 4.43 & $\begin{array}{l}\text { Cross- } \\
\text { sectional }\end{array}$ & $\begin{array}{l}\mathrm{N}=2,800 \\
\text { Age }=\text { less } \\
\text { than } 16, \\
16 / 17, \text { and } \\
18 / 19 \\
\text { Region = } \\
\text { Kenya, } \\
\text { Tanzania, } \\
\text { and } \\
\text { Uganda }\end{array}$ & $\begin{array}{l}\text { To describe } \\
\text { teenagers' } \\
\text { first births } \\
\text { by age }(<16, \\
17-17 \text {, and } \\
18-19)\end{array}$ & $\begin{array}{l}\text { Demographic } \\
\text { and } \\
\text { Household } \\
\text { Surveys and } \\
\text { Multiple } \\
\text { Indicator } \\
\text { Cluster } \\
\text { Surveys }\end{array}$ & $\begin{array}{l}\text { Adolescent first births, particularly at the } \\
\text { youngest ages, are most common among } \\
\text { the poorest and least education; Uganda } \\
\text { had the highest teen pregnancy followed } \\
\text { by Tanzania and Kenya, respectively }\end{array}$ \\
\hline $\begin{array}{l}\text { Pradhan et } \\
\text { al. (2015) }\end{array}$ & $\begin{array}{l}\text { Systematic } \\
\text { review }\end{array}$ & 10.5 & $\begin{array}{l}\text { Systematic } \\
\text { review }\end{array}$ & $\begin{array}{l}N=12 \\
\text { Age }=10-22 \\
\text { Region }=\text { low- } \\
\quad \text { and lower- } \\
\text { middle } \\
\text { income } \\
\text { countries }\end{array}$ & $\begin{array}{l}\text { To review } \\
\text { associated } \\
\text { factors with } \\
\text { adolescent } \\
\text { pregnancy } \\
\text { income } \\
\text { countries }\end{array}$ & $\begin{array}{l}\text { PRISMA, } \\
\text { Critical } \\
\text { Appraisal } \\
\text { Skills } \\
\text { Programme } \\
\text { tool }\end{array}$ & $\begin{array}{l}\text { Low or no education, low socioeconomic } \\
\text { status, and lack of employment are risk } \\
\text { factor for teenage pregnancy }\end{array}$ \\
\hline $\begin{array}{l}\text { Rojas et al. } \\
\quad(2016)\end{array}$ & Quantitative & 4.1 & $\begin{array}{l}\text { Retrospec- } \\
\text { tive cross- } \\
\text { sectional } \\
\text { survey } \\
2011 / 2012\end{array}$ & $\begin{array}{l}N=2,766 \\
\text { Age }=15-19 \\
\quad \text { Region }= \\
\text { Nicaragua }\end{array}$ & $\begin{array}{l}\text { To determine } \\
\text { whether } \\
\text { social } \\
\text { capital is } \\
\text { associated } \\
\text { with sexual } \\
\text { onset and } \\
\text { teen birth }\end{array}$ & $\begin{array}{l}\text { Demographic } \\
\text { and Health } \\
\text { Survey }\end{array}$ & $\begin{array}{l}\text { Higher education reduces first birth by } \\
38 \% \text {; higher number of females having a } \\
\text { child increases risk by } 76 \% \text {; social capital } \\
\text { plays a vital role on sexual onset and first } \\
\text { birth }\end{array}$ \\
\hline
\end{tabular}

Note. AMSTAR = assessment of multiple systematic reviews; PRISMA = Preferred Reporting Items for Systematic Reviews and MetaAnalyses. 
The full-text literature was retrieved in English from electronic databases and were then reviewed by the first author to assess eligibility; inclusion criteria were peer-reviewed studies including formal education, studies including teenage mothers (between the age of 13 and 19 years old), studies regarding low- and lower-middle-income countries (as defined by the World Bank), and studies published between January 2008 and July 2018. Exclusion criteria were studies regarding uppermiddle- and high-income countries, nonteenage pregnancy studies, studies not including education, non-English studies, case studies, dissertations, and books.

\section{Study Quality, Assessment, and Data Extraction}

For all included studies, the authors assessed the quality of the studies using PRISMA guidelines and AMSTAR measurement tool. After following the PRISMA guideline (see Figure 1), the authors independently scored all the articles with the AMSTAR measurement tool and averaged their scores (see Table 1). PRISMA is a 27-item checklist and a four-phase diagram that guides authors to provide a clear and transparent method of reporting (Moher et al., 20015. AMSTAR is a 16-item tool with validity to measure the quality of systematic reviews (Shea et al., 2017). For nonsystematic reviews, we only included five revised questions from the AMSTAR tool:

Question 1: Did the research study include the components of population, intervention or problem, comparator group, and outcome?

Question 9: Did the author(s) use a satisfactory technique for reducing the risk of bias in the study (e.g., statistical power, predefined variables, appropriate statistical procedures, ethical issues, credibility, etc.)?

Question 10: Did the author(s) report on sources of funding for the study?

Question 13: Did the author(s) account for the risk of bias when interpreting/discussing the results of the study (e.g., limitations, causal statement bias, publication bias, selective reporting bias, etc.)?

Question 16: Did the author(s) report any potential sources of conflict of interest, including funding?

Thus, these tools were used to ensure quality and reliability of the study, indicated by higher scores.

\section{Results}

\section{Study Characteristics}

In total, 4,980 articles were scanned. However, after the initial screening, 4,710 were removed because they did not meet the inclusion criteria, and after removing duplicates, only 86 articles were screened, of which 70 were excluded, and only nine articles fully met inclusion criteria. Of the nine articles, two articles used primary data (Aderibigbe et al., 2010, $M_{\text {AMSTAR }}=2.26$; Barmao-Kiptanui, Kindiki, \& Lelan, 2015, $M_{\text {AMSTAR }}=2.2$ ), five articles used secondary data (Ayuba \& Gani, 2012, $M_{\text {AMSTAR }}=2.93 ;$ Beguy, Ndugwa, \& Kabiru, 2013, $M_{\text {AMSTAR }}=4.6$; Exavery, Kanté, Mrema, Phillips, \& Masanja, 2016, $M_{\text {AMSTAR }}=3.83$; Neal, Chandra-Mouli, \& Chou, 2015, $M_{\text {AMSTAR }}=4.43 ;$ Rojas, Beogo, Owili, Adesanya, \& Chen, 2016, $M_{\text {AMSTAR }}=4.1$ ), and two articles were systematic reviews (Acharya, Bhattarai, Poobalan, Teijlingen, \& Chapman, 2010, $M_{\mathrm{AMSTAR}}=9.83$; Pradhan, Wynter, \& Fisher, $2015, M_{\text {AMSTAR }}=10.5$; See Table 1).

\section{Teenage Pregnancy and Education}

Educational attainment and teenage pregnancy are associated factors. Barmao-Kiptanui et al. (2015) found in their study $86 \%$ of their participants in Bungoma, Kenya, agreed teenage pregnancy leads 
to having a poorer educational outcome. In addition to pregnancy leading to poorer educational levels, parents' response to their teenage daughter's pregnancy played a role in their educational attainment; pregnant teenagers with supportive parents were able to go farther in their educational career than their counterparts. In a 4-year-long retrospective study, Ayuba and Gani (2012) reviewed records from a Nigerian hospital and compared 83 teenage pregnancies of girls who were between 13 and 19 years old with pregnancies of randomly selected pregnant women who were between 20 and 32 years old. They found most of the teenage mothers had lower educational attainment and were more at risk than the older subjects to pregnancy and birth complications, caesarean sections, and even death. Neal et al. (2015) found similar findings to Ayuba and Gani's study. In a cross-sectional descriptive study, Neal et al. used data from demographic and household surveys and multiple indicator cluster surveys to assess adolescent pregnancy characteristics such as age of motherhood, marital status, wealth, education, state or region, urban/rural residence, and religion in three east African countries (Uganda, Kenya, and Tanzania). They found younger girls who become pregnant are especially prone to complications and health risks during pregnancy and birth. Furthermore, younger adolescent first births are more prevalent among less educated girls and poorer areas, especially adolescent mothers who are under the age of 16 . Additionally, there is a strong association among adolescent motherhood, a lack of education and literacy, and poverty (Neal et al., 2015).

In evaluating 15- to 19-year-old adolescent girls' $(N=897)$ aspirations and protective and risk factors for childbearing, Beguy et al. (2013) used the urbanization, poverty, and health dynamics data. They found education and employment opportunities are negatively associated with teenage pregnancy. In addition, the best predictor for adolescent pregnancy was whether a teenager was currently enrolled in school or not, even after controlling for other factors. Adolescents who had attended secondary education had lower rates of teenage pregnancy than those who had attended less than secondary school. Moreover, the level of education was associated with the age at which an adolescent girl became pregnant and being enrolled in school delayed childbearing. Therefore, the longer an adolescent girl can stay in school, the higher her education level will be, and the lower the risk of teenage pregnancy is for her.

Similarly, Rojas et al. (2016) conducted a multilevel analysis using data from 2011/2012 demographic and health survey in Nicaragua $(N=2,766)$ to determine risks that might be associated with a teenager's sexual encounter. Education, social capital, low-income status, living in a neighborhood with a large population of teenage mothers, and not having religious affiliation were factors that impact first sexual encounter. For girls with higher educational attainment, it delayed their first sexual encounter and first birth. Aderibigbe et al. (2010) found similar findings in their study from Ilorin, Nigeria. They surveyed six public secondary schools $(N=521)$ and found $25.2 \%$ female teenagers had been sexually active, of which $5.7 \%$ of their sample were pregnant and $66.7 \%$ had been pregnant at least once. Furthermore, Aderibigbe et al. (2010) confirmed in their study based on induced abortions (100\%) teenage pregnancies are unwanted and not related to medical complications.

Pradhan et al. (2015) conducted a systematic literature review ( $N=12$ articles) to determine adolescent pregnancy factors in low-income and lower-middle-income countries. They found having limited or no education was a risk factor for adolescent pregnancy, risk of pregnancy was at least doubled for girls who only had lower levels of education, and girls who had higher levels of education reduced their risk of becoming pregnant. Furthermore, when their parents were educated, girls were sometimes more prone to postpone marriage and pregnancy. Pradhan et al. also found girls who had more years of formal education are more knowledgeable about healthy sexuality, contraception, and pregnancy. 
Similarly, Acharya et al. (2010) conducted a systematic review on teenage pregnancy to identify risk factors in Nepal, Bangladesh, India, and Sri Lanka $(N=10)$. They found four risk factors: socioeconomic status, educational level, culture, and the structure of the young person's family. Acharya et al. suggested having an education might help a young girl with self-confidence and postpone their first sexual encounter and marriage.

Finally, in a multilevel analysis study, Exavery et al. (2016) examined different trends and factors associated with teenage pregnancy by using longitudinal data of girls who gave birth before the age of 18 from the Rufiji Health and Demographic Surveillance System of Tanzania. They found the odds of an adolescent girl becoming pregnant decreases as the rate of a family's wealth increases.

Similarly, when girls had gained a secondary education, it reduced the rate of childbearing by $83 \%$. Alternately, the lower the levels of schooling, the higher the ratio of adolescent births, with the highest adolescent birth rate belonging to those who had no or little education. In their study, education was found to be the strongest associated factor with adolescent pregnancy, showing education is a protective factor against teenage pregnancy.

\section{Summary}

Those who live in low- and lower-middle-income countries are more likely to have less access to education, thus putting them at a higher risk of becoming adolescent mothers (Beguy et al., 2013; Neal et al., 2015; Odejimi, \& Bellingham-Young, 2014; Pradhan et al., 2015). Neal et al. (2015) reported that the highest rates of adolescent pregnancy are among those who have no education or only a primary education, especially for those who are under the age of 16 in Kenya, Tanzania, and Uganda. Neal et al.'s findings show how vital providing education and retaining girls in school at an early age is to reducing their risk of becoming an adolescent mother and, eventually, improving their quality of life. And, if social workers are involved to ensure healthy development for all youth occurs, this Grand Challenge for Social Work can be met, as social workers are on the frontline to aid in this endeavor.

\section{Discussion}

The aim of this study was to determine whether educational attainment for teenage girls in low- and lower-middle-income countries had any influence on their rate of teenage pregnancy. While many studies were initially identified with the used search terms, only nine peer reviewed articles met the criteria for inclusion. Many excluded studies focused on teenage pregnancy in low-income countries or education in low-income countries; the studies on education and teenage pregnancy together in low- and lower-middle-income countries were limited. Furthermore, many of the studies about education and teenage pregnancy in low- and lower-middle-income countries were from east Africa, which biases the sample on educational level on teenage pregnancy in other low- and lower-middleincome countries.

This study found an association between education and teenage pregnancy in low- and lower-middleincome countries. Teenage girls who had higher education or who remained in school longer generally delayed pregnancy longer than teenage girls who had little or no education or who were not in school at all (Beguy et al., 2013; Exavery et al., 2016; Neal et al., 2015; Pradhan et al., 2015). Teenage pregnancy led to poorer education (Barmao-Kiptanui et al., 2015). We found girls' educational level impacts the rate of teenage pregnancies, whereby young girls drop out of school during pregnancies and after birth to care for their child. Thus, this creates a cycle that perpetuates lower education and teenage pregnancy in low- and lower-middle-income countries. 
We found other factors that impact teenage pregnancy. However, we did not analyze these factors, as they were not within the scope our study, teenage pregnancy and educational attainment. These factors were: poverty (Exavery et al., 2016), rurality (Neal et al., 2015), being of a minority group, lack of contraception use (Pradhan et al., 2015), negative role models, marriage norm expectations, and religion (Beguy et al., 2013). These factors associated with teenage pregnancy are important to explore and to determine their full impact on teenage pregnancy and education, as it is one of our study's limitation.

This study adds evidence to the body of research that educational attainment and teenage pregnancy in low- and lower-middle-income countries are associated factors. No other studies were found that directly investigated the impact of educational levels on teenage pregnancy rates in low- and lowermiddle-income countries. Although we followed a systematic review and synthesized the data to offer knowledge on education and teenage pregnancy in low- and lower-middle-income countries, our study is limited. More studies are needed to determine the correlation between educational levels and teenage pregnancy in low-income countries. A meta-analysis, which includes statistical procedures to evaluate findings, could confirm our findings.

\section{Recommendations}

More research should be conducted in other low- and lower-middle-income countries besides the eastern region of Africa. Data about teenage pregnancy and education from other low- and lowermiddle-income countries could contribute to strengthen the argument that educational levels impact teenage pregnancy in low- and lower-middle-income countries. Most importantly, understanding what factors are associated with deterring girls from becoming school dropouts in these countries need to be well established, which could give insight into which interventions might be the most effective to combat this issue.

Based on the studies analyzed for this systematic review, social workers should focus on interventions that ensures enrollment of girls in schools in low- and lower-middle-income countries, provide opportunities for them to be able to attend school, and promote continued enrollment and attendance as young girls become teenagers. In addition to this, support services should be offered to teenage mothers in low- and lower-middle-income countries who have dropped out of school so they can re-enroll and earn a higher education. This could increase their future financial and career opportunities.

Social workers should focus on policy development in low- and lower-middle-income countries on education, which is necessary to postpone teenage pregnancy. Young girls need the help to remain in school, which simultaneously could decrease some of the societal burden of teenage pregnancy perpetuating poverty and increase young women's human capital and chances to succeed in their communities. If teenage pregnancy is delayed for young women and they are able to increase their education and human capital, this also increases the eventual outcome of their future families, which can help lead them out of poverty. Policies should also address any barriers young girls may face that would hinder their access to education or school attendance. This could address issues unrelated to teenage pregnancy or even education, such as barriers girls face within their families and communities in low- and lower-middle-income countries.

Furthermore, continued education opportunities and job trainings should be offered to older girls and young women, especially if they have given birth. In doing this, the women may be provided with an opportunity to advance economically. We found low socioeconomic status as a factor in increasing teenage pregnancy. Therefore, increasing a young woman's economic means and opportunity may help reduce poverty and prevent early pregnancy. In the case a young woman is a 
mother, social workers can provide education, awareness, and interventions that might reduce rates of pregnancy for the next generation of girls as they become adolescents, which would aid in breaking the cycle of poverty for these families.

\section{References}

Acharya, D. R., Bhattarai, R., Poobalan, A., Teijlingen, V. E., \& Chapman, G. (2010). Factors associated with teenage pregnancy in South Asia. Health Science Journal, 4, 3-14.

Aderibigbe, S. A., Araoye, M. O., Akande, T. M., Monehin, J. O., Musa, O. I., \& Babatunde, O. A. (2010). Teenage pregnancy and prevalence of abortion among in-school adolescents in north central, Nigeria. Asian Social Science, 7, 122.

Ayuba, I., \& Gani, O. (2012). Outcome of teenage pregnancy in the Niger delta of Nigeria. Ethiopian Journal of Health Sciences, 22, 45-50.

Azevedo, J. P., Favara, M., Haddock, S. E., Lopez-Calva, L. F., Muller, M., \& Perova, E. (2012). Teenage pregnancy and opportunities in Latin America and the Caribbean: On teenage fertility decisions, poverty and economic achievement. Retrieved from https://openknowledge.worldbank.org/bitstream/handle/10986/16978/831670v20REVIS00Box 385190B00PUBLIC0.pdf? sequence=5\&isAllowed $=\mathrm{y}$

Barmao-Kiptanui, C., Kindiki, J. N., \&Lelan, J. K. (2015). Impact of teenage motherhood on the academic performance in public primary schools in Bungoma county, Kenya. International Journal of Educational Administration and Policy Studies, 7, 61-71.

Beguy, D., Ndugwa, R., \& Kabiru, C. W. (2013). Entry into motherhood among adolescent girls in two informal settlements in Nairobi, Kenya. Journal of Biosocial Science, 45, 721-742.

Chandra-Mouli, V., McCarraher, D. R., Phillips, S. J., Williamson, N. E., \& Hainsworth, G. (2014). Contraception for adolescents in low and middle income countries: Needs, barriers, and access. Reproductive Health, 11, 1.

Decat, P., De Meyer, S., Jaruseviciene, L., Orozco, M., Ibarra, M., Segura, Z., . . . Degomme, O. (2014). Sexual onset and contraceptive use among adolescents from poor neighbourhoods in Managua, Nicaragua. The European Journal of Contraception \& Reproductive Health Care, $20,88-100$.

Exavery, A., Kanté, A. M., Mrema, S., Phillips, J. F., \& Masanja, H. (2016). Multilevel analysis of childbearing in childhood in Tanzania's Rufiji District. Maternal and Child Health Journal, $20,447-455$.

Ferre, Z., Gerstenblüth, M., Rossi, M., \& Triunfo, P. (2013). The impact of teenage childbearing on educational outcomes. The Journal of Developing Areas, 47, 159-174.

Gomes, K. R. O., Speizer, I. S., Gomes, F. M., Oliveira, D. D. C., \& Moura, N. B. (2008). Who are the pregnant adolescents in the poorest state capital of Brazil? Public Health Nursing, 25, 319326.

Grand Challenges in Social Work. (2019). Ensure healthy development for all youth. Retrieved from https://grandchallengesforsocialwork.org/ensure-healthy-development-for-all-youth/

Gupta N., \& Mahy M. (2003). Adolescent childbearing in sub-Saharan Africa: Can increased schooling alone raise ages at first birth? Demographic Research, 8, 93-106. 
Handa, S., Pineda, H., Esquivel, Y., Lopez, B., Gurdian, N. V., \& Regalia, F. (2009). Non-formal basic education as a development priority: Evidence from Nicaragua. Economics of Education Review, 28, 512-522.

Jonas, K., Crutzen, R., van den Borne, B., Sewpaul, R., \& Reddy, P. (2016). Teenage pregnancy rates and associations with other health risk behaviours: A three-wave cross-sectional study among South African school-going adolescents. Reproductive Health, 13, 50. doi:10.1186/s12978-016-0170-8

Mesa, A., \& Torres, M. E. (2016). The current state of young Hispanic children in South Carolina: Projections and implications for the future. Greenville, SC: Institute for Child Success. Retrieved from http://www.scpasos.org/wordpress/wp-content/uploads/2016/03/Young-Latinochildren-in-SC-report-2016.pdf

Michaelowa, K. (2000, June). Returns to education in low income countries: Evidence for Africa. Paper presented at the annual meeting of the Committee on Developing Countries of the German Economic Association. Frankfurt, Germany.

Moher, D., Shamseer, L., Clarke, M., Ghersi, D., Liberati, A., Petticrew, M., . . . Stewart, L. A., \& the PRISMA-P Group.(2015). Preferred reporting items for systematic review and meta-analysis protocols (PRISMA-P) 2015 statement. Systematic Reviews, 4, 1-9.

Neal, S. E., Chandra-Mouli, V., \& Chou, D. (2015). Adolescent first births in East Africa: Disaggregating characteristics, trends and determinants. Reproductive Health, 12, 1-13.

Odejimi, O., \& Bellingham-Young, D. (2014). A policy pathway to reducing teenage pregnancy in Africa. Journal of Human Growth and Development, 24, 135-141.

Odimegwu, C., \& Mkwananzi, S. (2016). Factors associated with teen pregnancy in sub-Saharan Africa: A multi-country cross-sectional study. African Journal of Reproductive Health, 20, 94-107.

Omar, K., Hasim S., Muhammad N. A., Jaffar A., Hashim S. M., \& Siraj H. H. (2010). Adolescent pregnancy outcomes and risk factors in Malaysia. International Journal of Gynecology \& Obstetrics, 111, 220-223.

Pradhan, R., Wynter, K., \& Fisher, J. (2015). Factors associated with pregnancy among adolescents in low-income and lower-middle-income countries: A systematic review. Journal of Epidemiology \& Community Health, 69, 918-924.

Rojas, B., Beogo, I., Owili, P., Adesanya, O., \& Chen, C. (2016). Community social capital on the timing of sexual debut and teen birth in Nicaragua: A multilevel approach. BMC Public Health, 16, 991.

Sahoo, H. (2011). Fertility behavior among adolescents in India. The Journal of Family Welfare, 57, $22-33$.

Samandari, G., \& Speizer, I. S. (2010). Adolescent sexual behavior and reproductive outcomes in Central America: Trends over the past two decades. International Perspectives in Sexual and Reproductive Health, 36, 26-35.

Santelli, J. S., Song, X., Garbers, S., Sharma, V., \& Viner, R. M. (2017). Global trends in adolescent fertility, 1990-2012, in relation to national wealth, income inequalities, and educational expenditures. Journal of Adolescent Health, 60, 161-168. 
Shea, B. J., Reeves, B. C., Wells, G., Thuku, M., Hamel, C., Moran, J., . . Henry, D. A. (2017). AMSTAR 2: A critical appraisal tool for systematic reviews that include randomised or nonrandomised studies of healthcare interventions, or both. BMJ, 358, j4008. doi:10.1136/bmj.j4008

Uehara, E. S., Barth, R. P., Olson, S., Catalano, R. F., Hawkins, J. D., Kemp, S. P., . . Sherraden, M. (2015). Identifying and tacking grand challenges for social work. Retrieved from http://aaswsw.org/wp-content/uploads/2015/12/WP3-with-cover.pdf

United Nations Population Fund. (2013). Motherhood in childhood: Facing the challenge of adolescent pregnancy. Retrieved from http://online.wsj.com/public/resources/documents/2013REPORT.PDF

World Bank. (2019). Poverty: Overview. Retrieved from https://www.worldbank.org/en/topic/poverty/overview

World Bank Data Team. (2019). New country classifications by income level: 2019-2020. Retrieved from https://blogs.worldbank.org/opendata/new-country-classifications-income-level-20192020

World Health Organization (WHO). (2014). Adolescent pregnancy. Retrieved from https://apps.who.int/iris/bitstream/handle/10665/112320/WHO_;jsessionid=7670926CF2A956 927193E6CFB4A40201? sequence=1

World Health Organization (WHO). (2018). Adolescent pregnancy. Retrieved from http://www.who.int/mediacentre/factsheets/fs364/en/

The Journal of Social Work in the Global Community, sponsored by Walden University, is a scholarly peer-reviewed journal that promotes research in the practice of international social work with a focus on social change. JSWGC publishes high-level research, literature and book reviews, and thought pieces related to the field of social work practice and social change in our global community.

Walden University Publishing: http://www.publishing.waldenu.edu 